\title{
Determination of Decay, Larvae Resistance, Water Uptake, Color, and Hardness Properties of Wood Impregnated with Honeybee Wax
}

\begin{abstract}
Çağlar Akçay
The aim of the study was to determine the effect of honeybee wax impregnation on the antifungal, larvicidal, water uptake, color, and mechanical properties of wood. Wood samples (poplar, Scots pine, beech, and lime) were impregnated with melted honeybee wax under vacuum. The wax-impregnated samples were exposed to the wood-decay fungi Trametes versicolor and Neolentinus lepideus for 8 weeks. The larvicidal effect of the beeswax was tested against European old house borer (Hylotrupes bajulus L.). Water uptake, color measurements, and surface hardness were also tested. According to the obtained findings, a $34.6 \%$ mass loss was seen in the poplar control wood, and only $3.9 \%$ mass loss was found in the $100 \%$ beeswax-impregnated samples. The results showed that $H$. bajulus larvae could digest honeybee wax with wood when beeswax surface treatment was applied. Additionally, an average of $30 \%$ larvae mortality rate was achieved on beeswax-treated wood surfaces, compared to a $2.5 \%$ rate on the controls. However, when wood was deeply treated with beeswax, larval mortality reached $100 \%$. In the water uptake test, beeswax-treated samples showed water repellent efficiency. The lowest water uptake $(24.2 \%)$ was obtained in poplar wood treated with $100 \%$ beeswax, compared to $92.6 \%$ in the poplar control in $96 \mathrm{~h}$ immersion time. With the beeswax treatment, $a^{*}$ and $b^{*}$ color values increased, while the $L^{*}$ values decreased.
\end{abstract}

Keywords: Honeybee wax; Impregnation; Decay; Hylotrupes bajulus; Water uptake; Color properties; Hardness

Contact information: Düzce University, Faculty of Forestry, Department of Forest Industrial Engineering, 81620, Düzce, Turkey; *Corresponding authors: caglarakcay@duzce.edu.tr

\section{INTRODUCTION}

Waxes have been used as a coating and surface material for many years (Lozhechnikova et al. 2017). Recently, the use of biocides has been limited due to American and European Union legal regulations (Kartal et al. 2006). Therefore, interest in the usage of waxes for wood protection has started to increase in terms of its ability to improve wood's absorption properties and dimensional stability. Wax treatment has also been reported to slow down the photo-degradation of wood (Lesar et al. 2011). Waxes benefit wood protection because, being natural and non-toxic, they do not cause harm to environmental systems or human health. The cell lumens of the wood impregnated with water-repellent waxes are filled with wax, thus increasing the wood's resistance to rot. Therefore, fungal degradation of the wood impregnated with hydrophobic wax is slowed (Lesar and Humar 2011).

It has been reported that treatment with waxes also protects against termites, though it cannot completely stop the damage (Scholz et al. 2010a). Waxes also increase the 
mechanical properties of wood. The hardness, compression resistance, bending strength, and impact bending strength values of wood impregnated with different wax types increase (Krupa and Luyt 2001; Esteves et al. 2014). Waxes, including beeswax, are widely used in the conservation and consolidation of wooden works (Timar et al 2010; Hutanu et al. 2013)

Waxes are natural and renewable materials. The melting temperature of beeswax depends on the geographical region, but it is generally between 61 and $67{ }^{\circ} \mathrm{C}$ (Gaillard et al. 2011). Waxes also show high plastic properties at low temperatures. It has been reported that their density varies between 0.958 and $0.970 \mathrm{~g} / \mathrm{cm}^{3}$, while thermal conductivity is 0.25 $\mathrm{W} / \mathrm{mK}$ (Morgan et al. 2002). There are approximately 300 different components in beeswax. It mostly consists of $14 \%$ hydrocarbons, $12 \%$ free fatty acids, $35 \%$ mono esters, $14 \%$ diesters, $3 \%$ triesters, $4 \%$ hydroxy monoesters, $8 \%$ hydroxy polyester, $1 \%$ monoester acids, and 2\% polyester acids (Marquez et al. 2019).

Beeswax has a wide variety of applications, from basic honeycomb production in the beekeeping industry to the cosmetic industry. It is used for various purposes in woodworking, including to polish parquet varnish and in paint. Beeswax is used to make metallic containers and bottle caps, small sculptures, and trinkets. It is also used in the production of candles, perfume, and cosmetic lipsticks (Bogdanov 2009). Beeswax is widely used in shoemaking, water-resistant yarn production, waterproofing tents and other materials, medical purposes, and in many other fields. It is also reported that wax is used to produce various types of ointment drugs for human health, as well as in the production of facial creams and dentistry (Tulloch 1980; Mladenoska et al. 2012).

The aim of the present study was to investigate the effect of wax impregnation on the biological, mechanical, and physical properties of certain wood species with low durability. According to the author's knowledge, the effects of beeswax impregnation on wood's ability to withstand old house borer, as well as its effects on wood's color and hardness properties, have not been tested in the literature.

\section{EXPERIMENTAL}

\section{Wood Samples}

Poplar (Populus alba L.), lime (Tilia grandifolia Ehrh.), Scots pine (Pinus sylvestris L.), and beech (Fagus orientalis L.) wood species were supplied from Düzce Province, Turkey. Wood specimens were prepared from sapwood in dimensions of $50 \times 10 \times 5 \mathrm{~mm}^{3}$ for fungal tests and to observe color and hardness properties. Samples were sized $50 \times 25 \times 15 \mathrm{~mm}^{3}$ for larvae test, and $50 \times 10 \times 5 \mathrm{~mm}^{3}$ (longitudinal $\times$ radial $\times$ tangential) for water uptake (WU). Oven dry densities of poplar, lime, Scots pine, and beech wood species were recorded as $0.43,0.47,0.52$, and $0.58 \mathrm{~g} / \mathrm{cm}^{3}$, respectively. The ring widths were measured with an approximate average of $5 \mathrm{~mm}$ for each wood species used in the study.

\section{Impregnation of Wood Samples}

Beeswax was obtained from Aktarix Bitkisel Ürünler Company, Antalya, Turkey. Its melting point was $61^{\circ} \mathrm{C}$. Six replicates were used for each species in wax impregnation. All samples specimens were dried at $103 \pm 2{ }^{\circ} \mathrm{C}$ for $24 \mathrm{~h}$, and the dried weights $\left(G_{0}\right)$ were recorded before the impregnation process. The impregnation process was completed in a desiccator. The desiccator was put on a heater held at $120{ }^{\circ} \mathrm{C}$. The test specimens, except the controls, were placed into the melted beeswax solution in the desiccator and kept under 
a vacuum of $0.079 \mathrm{MPa}$ for $60 \mathrm{~min}$. After impregnation, the remaining beeswax was rapidly wiped away with a paper towel. Next, the beeswax-impregnated samples were weighed $\left(G_{1}\right)$. The rate of weight gain (WPG) of the samples was calculated using Eq. 1. All samples were conditioned at $20 \pm 2{ }^{\circ} \mathrm{C}$ and $65 \pm 2 \%$ relative humidity (RH) for two weeks after treatment. The relative change in weight was calculated as follows:

$$
\triangle G(\%)=\left(G_{1}-G_{0}\right) / G_{0} \times 100
$$

\section{Antifungal Test}

The decay resistance of beeswax-treated poplar, lime, Scots pine, and beech wood specimens against white rot Trametes versicolor (TV) and brown rot Neolentinus lepideus (NL) was tested according to the EN 113 (1996) standard. Six replicates were used for each species in antifungal testing. Malt extract agar (MEA) medium (Merck, Darmstadt, Germany) (3\%) was used to grow fungi cultures. The media were sterilized at $121 \pm 2{ }^{\circ} \mathrm{C}$ and $1.1 \mathrm{~atm}$ for $20 \mathrm{~min}$. Wood blocks were sterilized in a UV-featured biohazard safety cabined (JSR Research Inc., Gongju, Republic of Korea) for 90 min so that the beeswax did not leach from the wood samples at high temperature. The media were transferred to petri dishes. After inoculation, the dishes were kept at $26 \pm 2{ }^{\circ} \mathrm{C}$ and $80 \% \mathrm{RH}$. When the media surfaces were completely colonized by the test fungi, beeswax-treated and untreated wood samples were placed into the petri dishes. The wood samples were exposed to white rot (T. versicolor) and brown rot (N. lepideus) in an incubator at $26 \pm 2{ }^{\circ} \mathrm{C}$ and $80 \% \mathrm{RH}$ for 8 weeks. T. versicolor was obtained from RISH, Kyoto University, Japan. N. lepideus was isolated from decayed wood in a log depot of Bolu province in Turkey. After the fungal exposure, exposed wood samples were cleaned from the fungal mycelium using a brush. Cleaned samples were dried at $55{ }^{\circ} \mathrm{C}$ for $48 \mathrm{~h}$ and reweighed (control samples were dried overnight at $103 \pm 2{ }^{\circ} \mathrm{C}$ ). Then, percent mass losses were calculated using the weights recorded before and after the fungal tests (Eq. 2). Decay resistance tests were conducted in the Forest Biology and Wood Preservation Laboratory of Düzce University (Düzce, Turkey). The weight loss (Eq. 2) was determined as follows,

$$
\mathrm{WL}=\left[\left(M_{1}-M_{0}\right) / M_{1}\right] \times 100
$$

where $M_{1}$ is the weight of wood (g) after wax treatment and before the fungal test and $M_{0}$ is the weight $(\mathrm{g})$ of the wood after the fungal test.

\section{Larvae Test}

The larvae tests were conducted according to EN 46-1 (2016) and EN 47 (2016) standards. Surface treatment was applied according to EN 46 -1 (2016), while EN 47 followed for the deep impregnation process. Scots pine (four replicates) test specimens were cut into dimensions $25 \times 15 \times 5 \mathrm{~mm}^{3}$. For the control and beeswax-treated samples, a gap was created in one side of the specimens for placement of the larvae, while the other surfaces were covered with paraffin wax. Newly hatched Hylotrupes bajulus (Coleoptera: Cerambycidae) larvae obtained from the end of cultivation were used for the larvae test according to the standard EN 46-1 (2016). A total of 10 larvae were inserted between glass and wood surfaces for one wood block. All wood blocks included controls, and 80 larvae were used in the experiment. Wood blocks were kept at $26 \pm 2{ }^{\circ} \mathrm{C}$ and $80 \%$ relative humidity. After four weeks, the glasses were removed on the wood block surfaces, and the living and dead larvae were recorded (classified as not tunneled, starting to tunnel, alive, and tunneled) under a microscope. Then, the test continued until the end of the 16 weeks. 
After testing, all wood blocks were cut and the amount of live and dead larvae was determined. Larvae mortality rates were calculated by using Eq. 3.

Four replicates were used for the deeply impregnation. Six larvae were inserted on the hole opened on the wood. A total of 48 newly hatched larvae were used, which includes control samples according to the EN 47 standard (2016). Wood blocks were kept under the same conditions with surface treatment samples in a conditioner. All wood blocks were cut after 16 weeks and the amount of live and dead larvae was recorded. Larvae mortality rates were calculated by using Eq. 3,

$$
\text { Mortality }=\left(N_{\mathrm{f}} / N_{\mathrm{t}}\right) \times 100
$$

where the total larvae number before testing is $N_{\mathrm{t}}$ and the number of dead larvae after testing is $N_{\mathrm{f}}$.

\section{Water Uptake Test}

A total of 48 samples from poplar, lime, Scots pine, and beech were used for WU tests. Control samples were dried to a constant weight at $103 \pm 2{ }^{\circ} \mathrm{C}$; their dry weights were re-measured to the nearest $0.01 \mathrm{~g}\left(A_{0}\right)$. All specimens were conditioned at $20 \pm 2{ }^{\circ} \mathrm{C}$ and $65 \pm 2 \% \mathrm{RH}$ for 2 weeks before the WU test. The weights after impregnation were used as $A_{0}$ for WU tests, while oven-dried weights were used for the control samples. The beeswax-treated and control samples were immersed in water with $20 \pm 1{ }^{\circ} \mathrm{C}$, and a heavy stone was put on them to ensure that they remained below the water surface. The weights of the test and control samples were measured at the end of water immersion periods of 1 , $2,4,8,16,32,48,60,72$, and $96 \mathrm{~h}\left(A_{1}\right)$. At the end of each period, the samples were removed from the water container and wiped off with a paper towel. The WU was calculated with following Eq. 4:

$$
W U=\left[\left(A_{1}-A_{0}\right) / A_{0}\right] \times 100
$$

The WRE of the beeswax used in the study was calculated using Eq. 5 for each test separately,

$$
W R E=\left[\left(A_{\mathrm{C}}-A_{1}\right) / A_{\mathrm{C}}\right] \times 100
$$

where, $A_{\mathrm{C}}$ is the water uptake of the control sample, and $A_{1}$ is the water uptake of the test sample at the end of the specified periods.

\section{Determination of Color Measurement}

Ten replicates were used for control and beeswax treated samples. Red/green color tone $\left(a^{*}\right)$, lightness $\left(L^{*}\right)$, and the yellow/blue color tone $\left(b^{*}\right)$ of wax-treated and untreated specimens was determined using a CS-10 colorimeter (Hangzhou CHNSpec Technology Co., Ltd., Hangzhou, China), a CIE $10^{\circ}$ standard observer; and a CIE D65 light source, with $8 \%$ diffused illumination, according to ASTM standard D2244-16 (2016). A CIELAB system, characterized by the three-axis $L^{*}, a^{*}$, and $b^{*}$ was used (Ayata 2019). The total color difference $\left(\Delta E^{*}\right), \Delta a^{*}, \Delta L^{*}$, and $\Delta b^{*}$ were calculated using Eqs. 6, 7, 8, and 9:

$$
\begin{aligned}
& \Delta E^{*}=\left[\left(\Delta L^{*}\right)^{2}+\left(\Delta a^{*}\right)^{2}+\left(\Delta b^{*}\right)^{2}\right]^{1 / 2} \\
& \Delta L^{*}=L^{*} \text { Wax-treated }-L^{*} \text { untreated } \\
& \Delta b^{*}=b^{*} \text { Wax-treated }-b^{*} \text { untreated } \\
& \Delta a^{*}=a^{*} \text { Wax-treated }-a^{*} \text { untreated }
\end{aligned}
$$




\section{Determination of Shore D Hardness}

Shore D hardness (stand: model Ld-J Loyka; Shenzhen Omena Technology Co., Ltd., Guangdong, China) was loaded with 5 kg using ASTM D2240-15 (2010) standard. Ten tests were performed for untreated and wax-treated samples.

\section{Statistical Analysis}

Minimum, maximum, and average values, as well as variance analysis, homogeneity groups were given for color and Shore D hardness tests on samples that were wax-treated and untreated. The SPSS 17 program (Sun Microsystems, Inc.; Santa Clara, CA, USA) was used in Statistical Analysis

\section{SEM Analysis}

Scanning electron microscopy (SEM) analyses were performed at Düzce University Scientific and Technological Researches Application and Research Center (Düzce, Turkey). The SEM images were taken using a Quanta FEG 250 instrument (FEI Europe B.V., Eindhoven, Netherlands). The wood samples were mounted onto aluminum stubs with double-sided carbon tape, and the mounted specimens were coated with $10 \mathrm{~nm}$ gold film using a sputter coater (Desk V-Standard; Denton Vacuum, LLC, Moorestown, NJ, USA) before analyses. Surface morphologies of the samples were investigated with an SEM Quanta FEG 250 (FEI Europe B.V., Eindhoven, Netherlands), which used an electron acceleration voltage of $10 \mathrm{keV}$. The images showed the radial section of the woods.

\section{RESULTS AND DISCUSSION}

\section{Weight Gain}

As shown in Fig. 1, the highest $\Delta G$ was recored in beeswax-impregnated poplar samples, while the lowest was recorded in beech. It seemed that $\Delta G$ was related to the densities of wood species. When wood densities decreased, the $\Delta G$ value increased, as shown in Fig. 1.

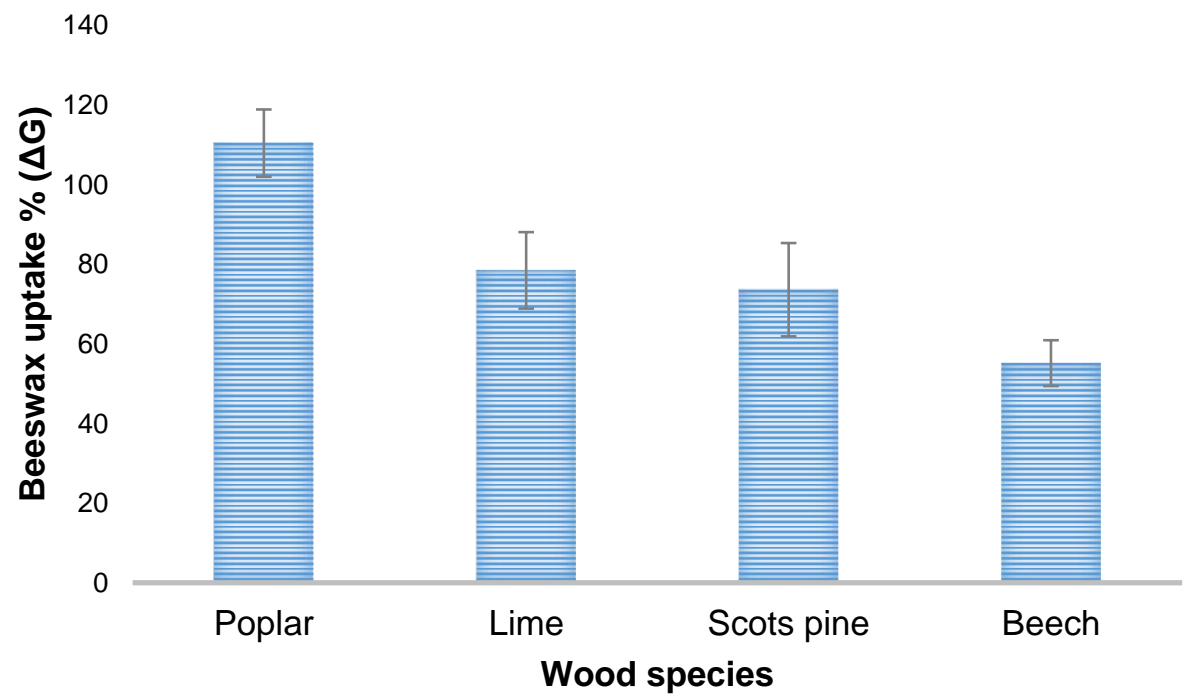

Fig. 1. Weight gain rate of the wood specimens (note: error bars indicate standard deviation) 


\section{Fungal Test}

Antifungal properties of the beeswax-impregnated samples are given in Fig. 2. The highest mean weight losses were detected in control samples of the woods. Poplar control samples exposure to N. lepideus and T. versicolor gave higher weight losses by $34.6 \%$ and $33 \%$, respectively, compared to the other wood species. When wood species were impregnated with beeswax at the concentration of $100 \%$, weight losses decreased in all wood species. Only $3.9 \%$ mass loss occurred in poplar wood impregnated with $100 \%$ honeybee wax in impregnated specimens. In general, weight loss in both the control and the beeswax-impregnated specimens in terms of the decomposition of fungal species gave similar results. Melted wax was filled into the cell lumens of the wood impregnated with beeswax, thus giving water-repellent properties to beeswax-impregnated wood (Németh $e t$ al. 2015). For this reason, fungal development is prevented in wood with reduced moisture content.

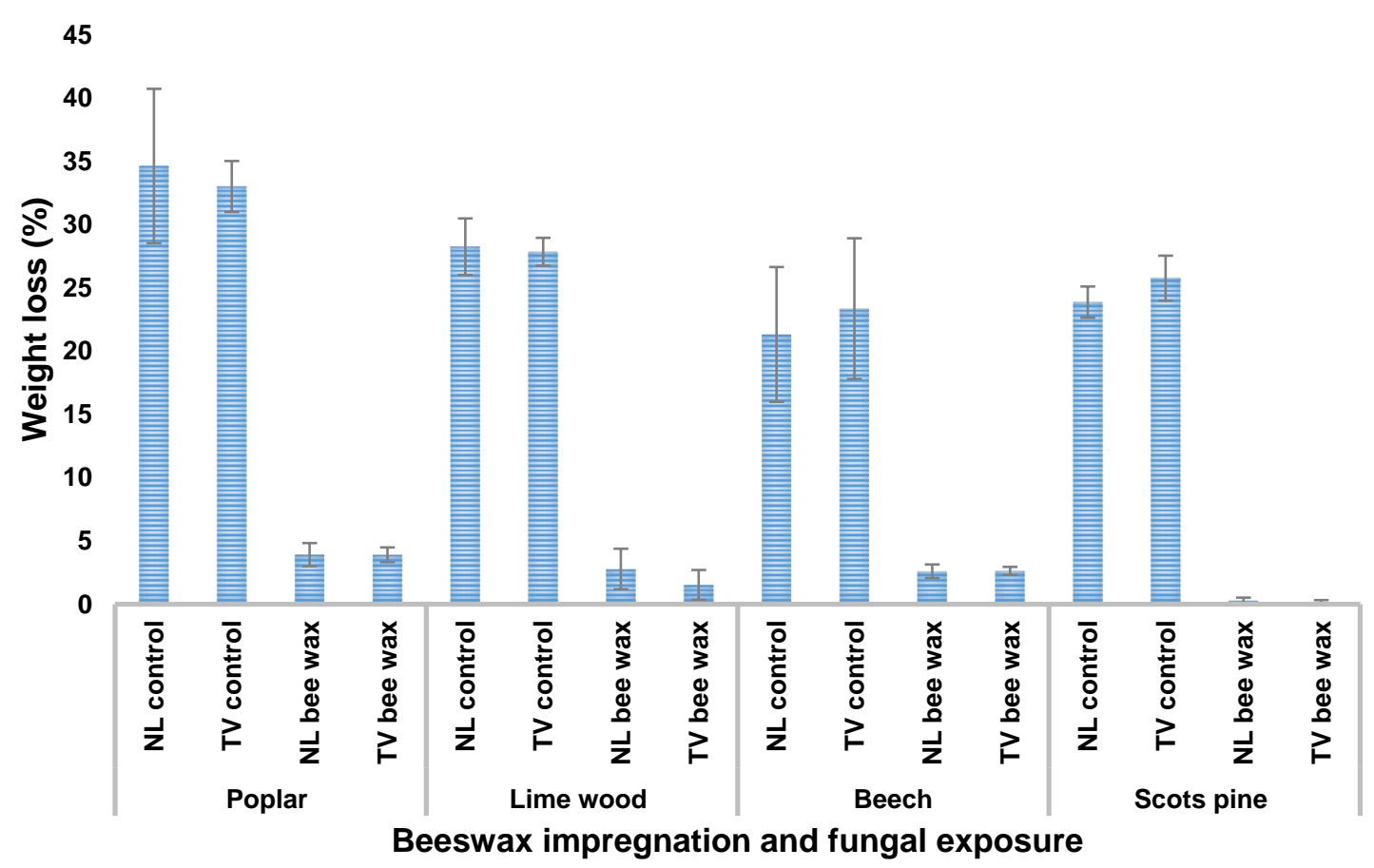

Fig. 2. Antifungal properties of beeswax impregnation (note: NL: Neolentinus lepideus, TV:

Trametes versicolor, error bars indicate standard deviation)

Figure 3 shows SEM images of poplar wood impregnated with honeybee wax and exposed to wood decay fungi. According to the SEM images, there was a dense fungal hyphae in the trachea of wood species that were not impregnated with honeybee wax, while hyphae were not detected in the trachea of the impregnated wood species. In addition, a large amount of wax was observed in the trachea of the lumens in the images of impregnated samples. It is understood that wood cell lumens filled with the beeswax prevent the spread of fungal hyphae (Nemeth et al. 2015). It can also be said that fungi cannot develop under such circumstances, as there is no moisture in cell lumens filled with beeswax. 


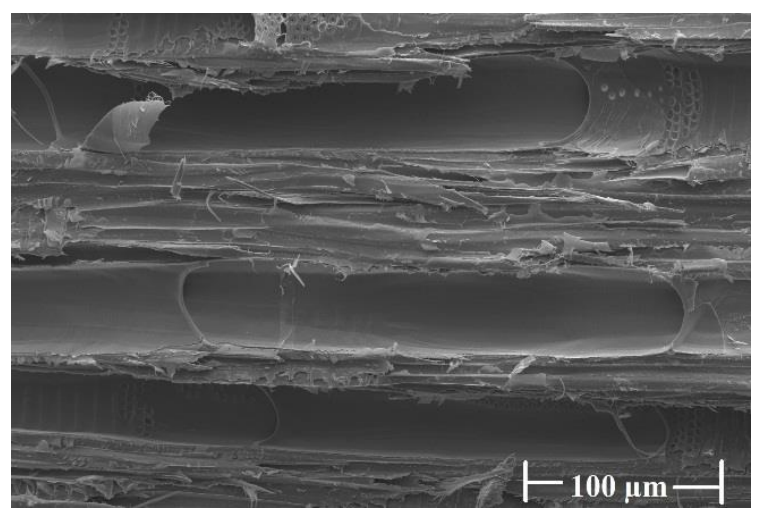

a)

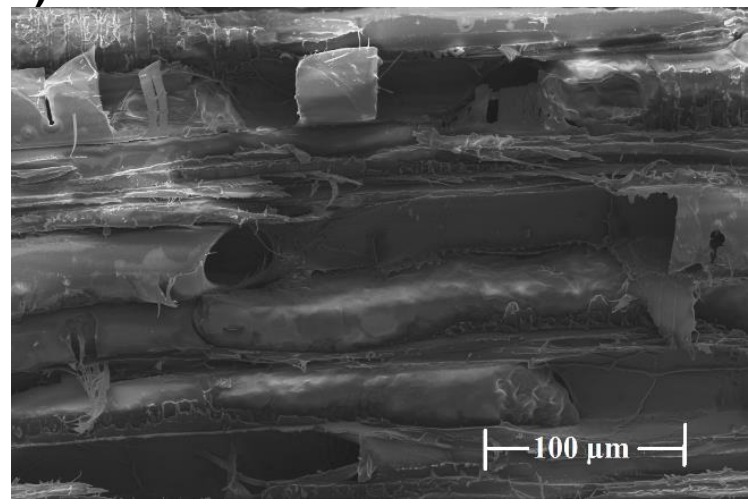

c)

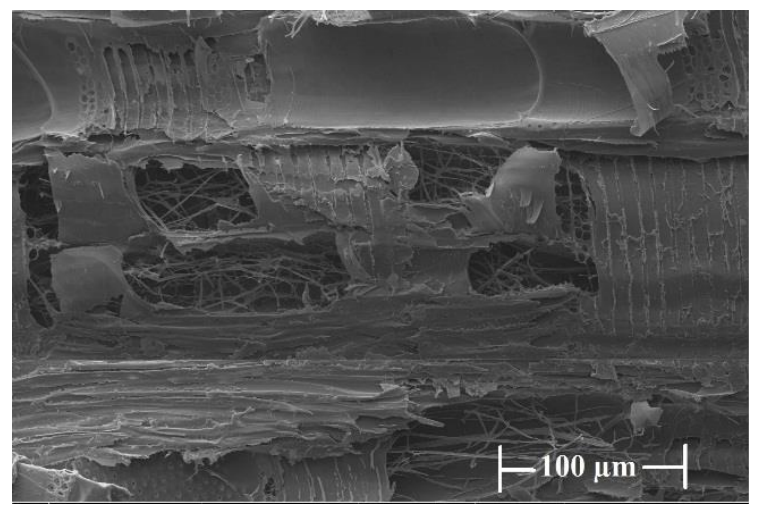

b)

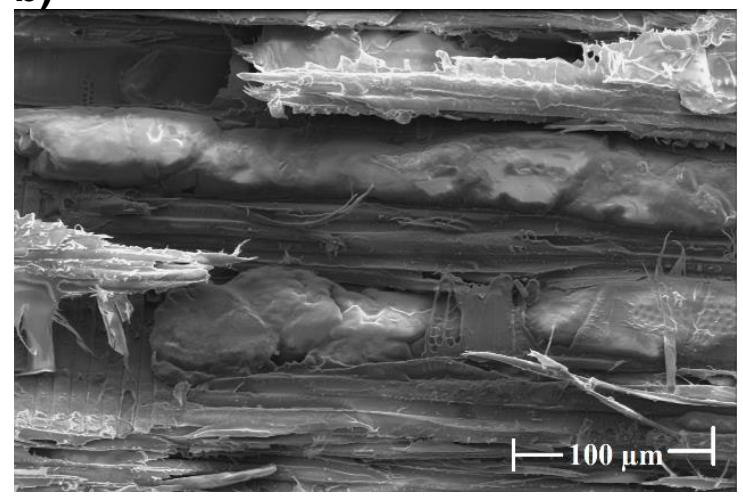

d)

Fig. 3. Scanning electron microscopy images of control and beeswax-treated poplar wood: a) unimpregnated control, b) un-impregnated and exposed to decay fungi, c) beeswax-impregnated, and d) beeswax-impregnated and exposed to decay fungi

\section{Larvae Test}

Larvae mortality rates of beeswax-treated and control woods after four and 16 weeks are shown in Table 1 . As shown, mean larvae mortality rate was recorded as $2.5 \%$ in the control woods. When wood species were surface treated with beeswax, the mean percentage larvae mortality rate reached $30 \%$. Almost all the larvae in the control woods were alive and tunneled. The highest mortality rate on the surface observed was $70 \%$ in the wood sample treated with $1.52 \mathrm{~g}$ of beeswax, and the lowest was observed in the sample surface treated with $1.02 \mathrm{~g}$ of beeswax. Thus, as the beeswax amount inceased, the larvae mortality increased. As a result of examinations under the microscope, it was observed that some larvae digested the beeswax and discarded it in the frass form. In addition, as a result of the microscope observations, it was observed that the larvae mostly died before they passed the wax layer, and the larvae that reached the wood continued feeding. According to these findings (surface treatment), beeswax impregnation protected wood against $H$. bajulus but did not completely stop the damage. Similar findings have also been reported for termites by Scholz et al. (2010a). Nemeth et al. (2015) detected insect damage on the surface of beeswax-impregnated beech wood. They reported that wood-boring beetles could digest beeswax together with wood because beeswax has a low biocide effect on insects. However, the current study showed that when Scots pine samples were deeply impregnated with beeswax, the larval mortality rate was obtained as $100 \%$ (Table 1). According to these findings, beeswax can be used effectively against $H$. bajulus when wood deeply treated. 
Table 1. Larvae Mortality Rates on Scots pine Wood Surfaces Treated with Beeswax

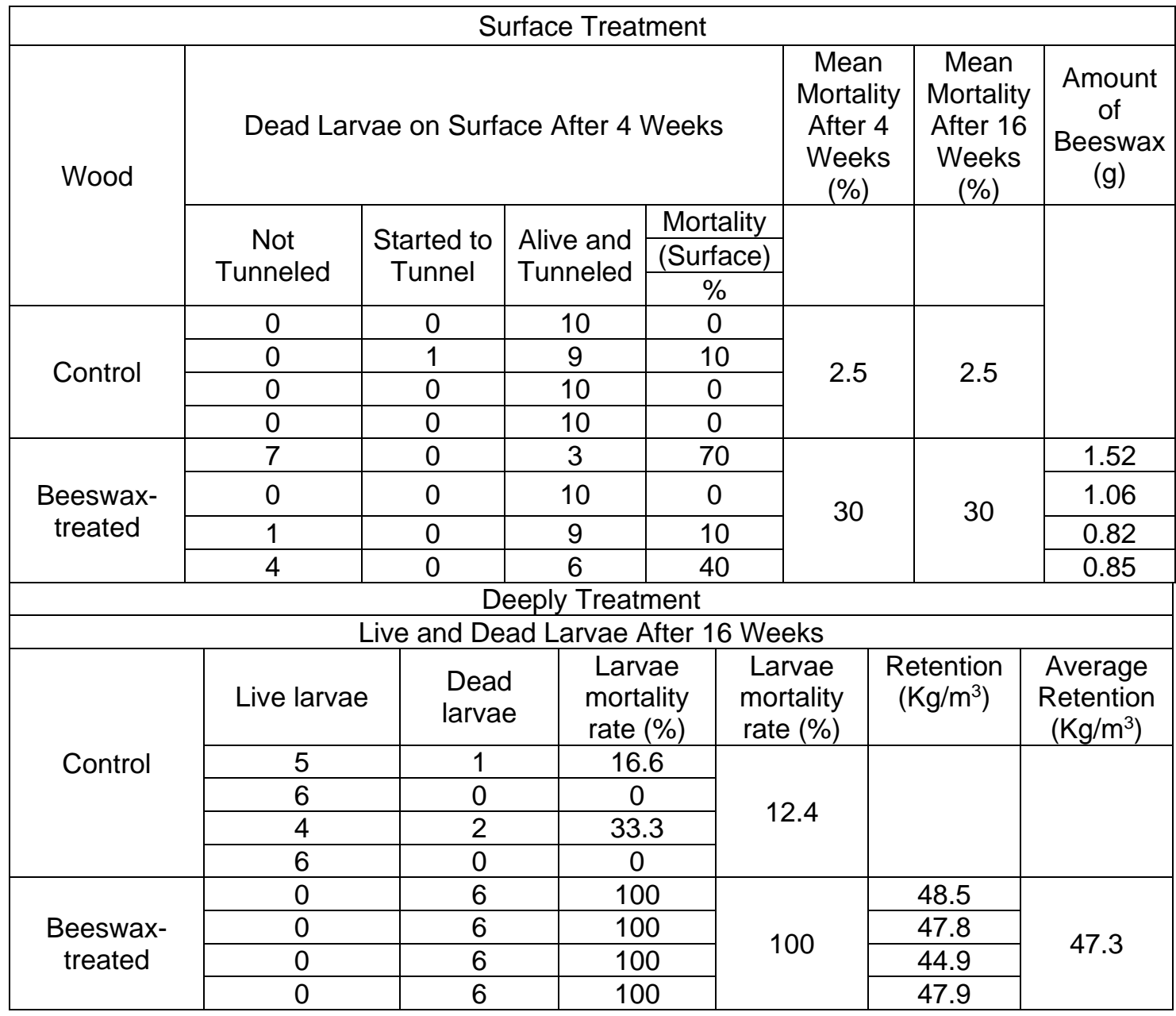

\section{Water Uptake of Wood Species Impregnated with Beeswax}

Mean water uptake (WU) for control and beeswax-impregnated poplar, lime, Scots pine, and beech wood samples with immersion time is shown in Figs. 4 through 7. Generally, it was seen that water uptake values for beeswax-impregnated wood were much lower than for un-impregnated control samples. Water uptake values for controls and beeswax-impregnated samples increased rapidly from the start of immersion until approximately $48 \mathrm{~h}$ of immersion. After that time, mean water uptake increase rates decreased notably, and they remained nearly constant except in the poplar control wood. The water-uptake increase rate for beeswax-treated wood samples was much lower than that of control woods during the immersion time. The highest WU $(92.6 \%)$ was found in the poplar control wood, and the lowest was seen in the beech control with a 96-h immersion time. Beeswax-impregnated poplar (24.6\%) and beech $(24.2 \%)$ wood showed the lowest WU in the impregnated samples, although poplar wood's corresponding control had the highest WU at the end of the immersion time. According to obtained results, beeswax impregnation provided the high-water repellent efficiency (WRE). Even under 96 $\mathrm{h}$ of immersion, $276.4 \%$ water repellent efficiency was obtained in beeswax-impregnated poplar wood, while $114.1 \%$ WRE was obtained in beeswax-treated beech. 
Water uptake is related to wood species density (Ding et al. 2012). Because poplar wood used in the study had the lowest density, it gave the highest WU and WRE values. Resins, paraffins, and waxes are hydrophobic and water repellent substances (Zhang et al. 2007), as well as insoluble in water. When wood is impregnated with wax, it locates in the cell lumen and forms a thin layer at the wood's surface (Ding et al. 2012; Ren et al. 2016). It reduces swelling of the wood (Ding et al. 2012). Moreover, beeswax impregnation increases the surface contact angle between wood and water. Thus, beeswax impregnation improved the hydrophobic properties of the wood surfaces. Li et al. (2020) concluded that beeswax impregnation remarkably enhanced the dimensional stability, water absorption, and surface hygroscopicity of wood.

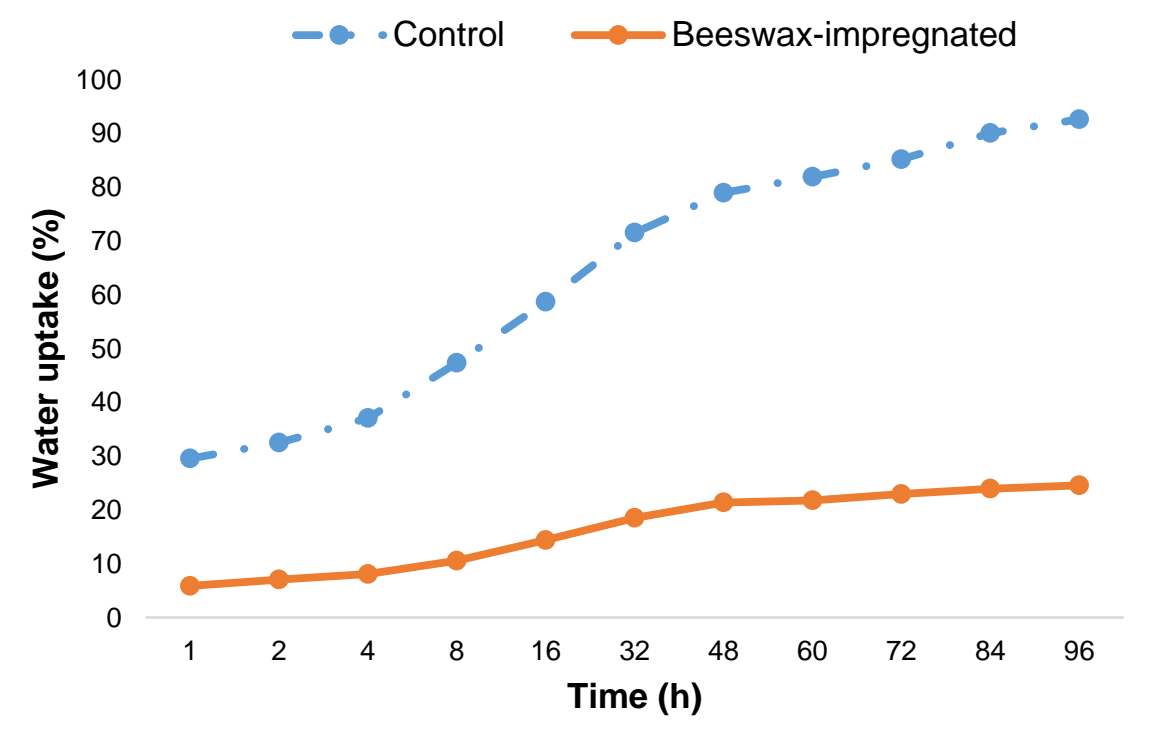

Fig. 4. The WU of poplar wood treated with beeswax at different water-holding periods

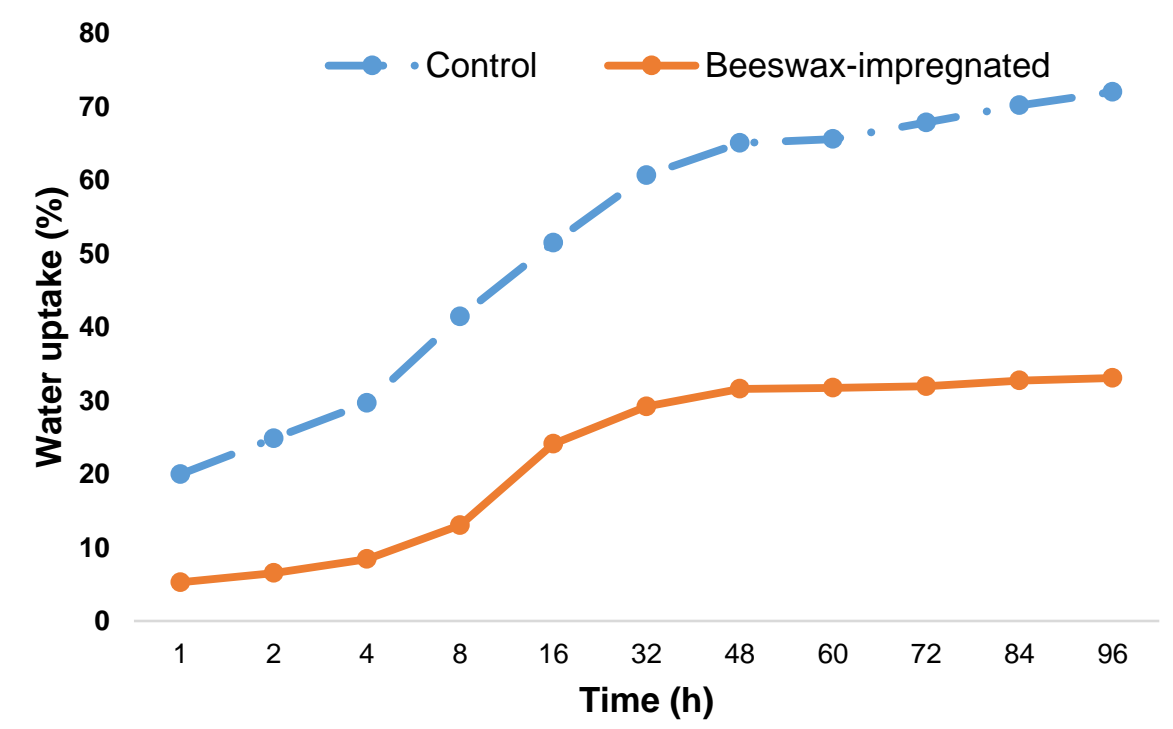

Fig. 5. The WU of lime wood treated with beeswax at different water-holding periods 


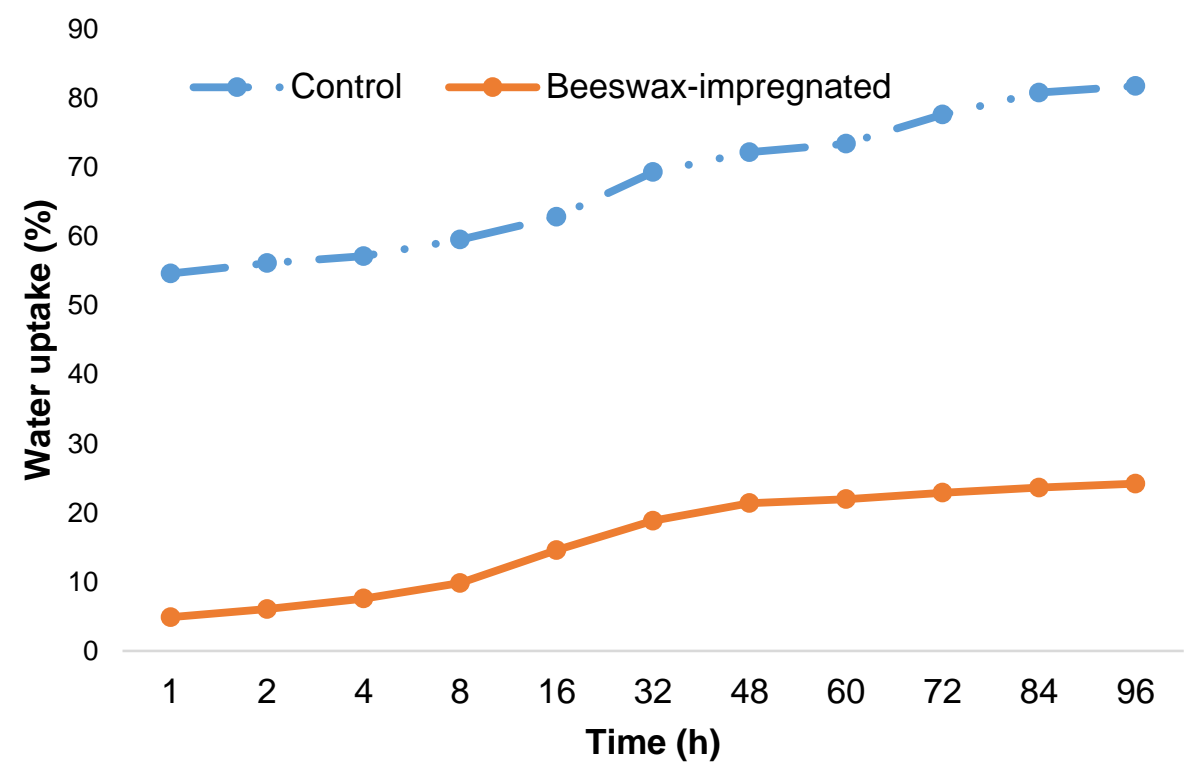

Fig. 6. The WU of Scots pine wood treated with beeswax at different water-holding periods

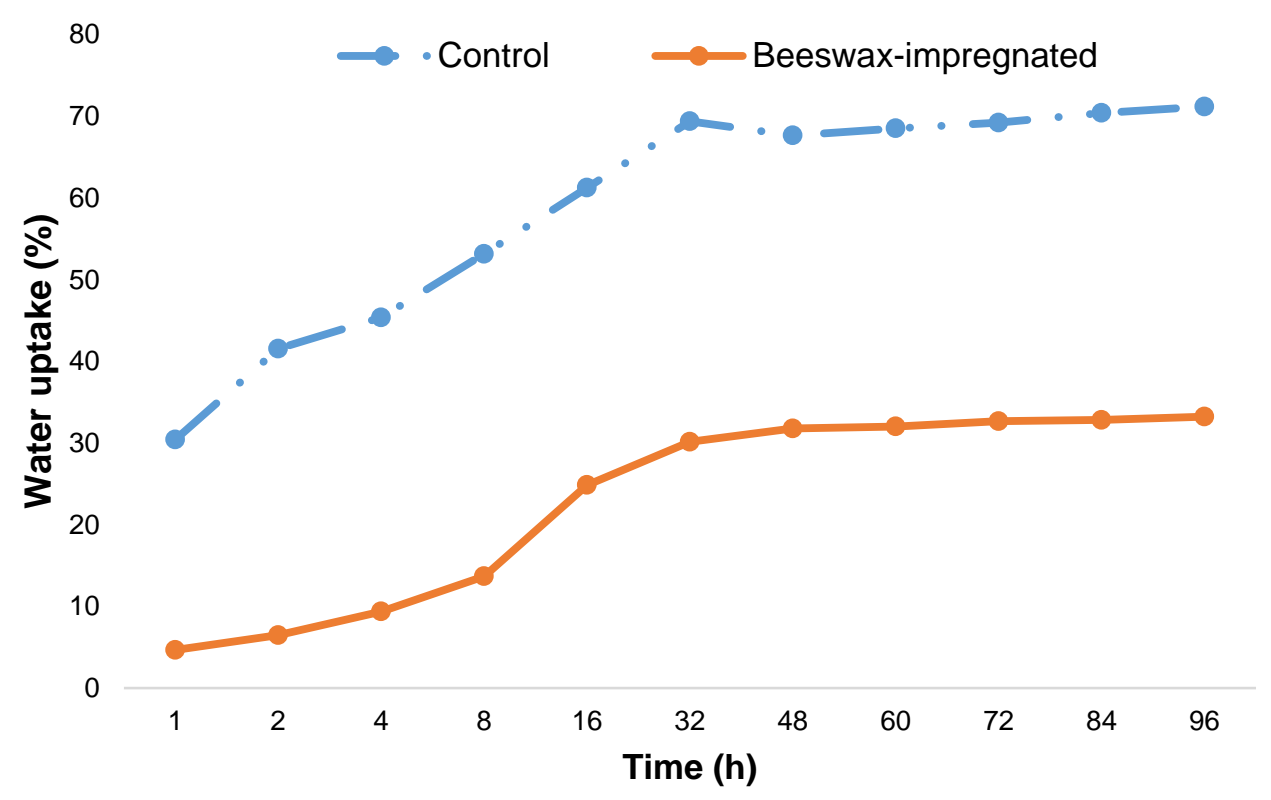

Fig. 7. The WU of beech wood treated with beeswax at different water-holding periods

\section{Color and Hardness Changes}

Table 2 shows the results of variance analysis for $\Delta L^{*}, \Delta a^{*}, \Delta b^{*}$, and Shore D. According to wood type (A), impregnation (B), fungi type (C), and interaction (AB, AC, $\mathrm{BC}$, and $\mathrm{ABC})$ for $L, a^{*}, b^{*}$, and Shore $\mathrm{D}$ were significant at $95 \%$ confidence level $(\mathrm{P} \leq$ $0.05)$. 
Table 2. Results of the Variance Analysis of Color Parameters $\left(a^{*}, b^{*}\right.$, and $\left.L^{*}\right)$ and Shore D Hardness Before and After Fungi Tests

\begin{tabular}{|c|c|c|c|c|c|c|}
\hline Test & Source & $\begin{array}{c}\text { Sum of } \\
\text { Squares }\end{array}$ & $\begin{array}{l}\text { Degrees of } \\
\text { Freedom }\end{array}$ & Mean Square & $\mathrm{F}$ & Sig. \\
\hline \multirow{9}{*}{ 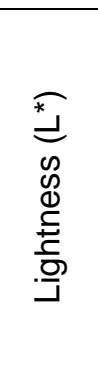 } & Wood Type (A) & 3740.402 & 3 & 1246.801 & 3348.925 & $0.000^{*}$ \\
\hline & Impregnation (B) & 14422.286 & 1 & 14422.286 & 38738.466 & $0.000^{*}$ \\
\hline & Interaction $(\mathrm{AB})$ & 2480.285 & 3 & 826.762 & 2220.694 & $0.000^{*}$ \\
\hline & Fungi Type (C) & 157.401 & 2 & 78.700 & 211.390 & $0.000^{*}$ \\
\hline & Interaction (AC) & 2035.495 & 6 & 339.249 & 911.228 & $0.000^{*}$ \\
\hline & Interaction (BC) & 334.585 & 2 & 167.292 & 449.350 & $0.000^{*}$ \\
\hline & Interaction (ABC) & 496.231 & 6 & 82.705 & 222.147 & $0.000^{*}$ \\
\hline & Error & 80.417 & 216 & 0.372 & & \\
\hline & Total & 1154727.021 & 240 & & & \\
\hline \multirow{9}{*}{ 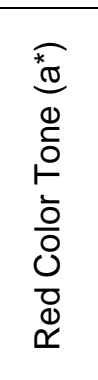 } & Wood Type (A) & 433.263 & 3 & 144.421 & 1738.234 & $0.000^{*}$ \\
\hline & Impregnate (B) & 124.805 & 1 & 124.805 & 1502.138 & $0.000^{*}$ \\
\hline & Interaction $(\mathrm{AB})$ & 18.479 & 3 & 6.160 & 74.138 & $0.000^{*}$ \\
\hline & Fungi Type (C) & 4.149 & 2 & 2.075 & 24.969 & $0.000^{*}$ \\
\hline & Interaction (AC) & 1009.590 & 6 & 168.265 & 2025.217 & $0.000^{*}$ \\
\hline & Interaction (BC) & 138.722 & 2 & 69.361 & 834.821 & $0.000^{*}$ \\
\hline & Interaction (ABC) & 107.870 & 6 & 17.978 & 216.385 & $0.000^{*}$ \\
\hline & Error & 17.946 & 216 & 0.083 & & \\
\hline & Total & 14163.582 & 240 & & & \\
\hline \multirow{9}{*}{ 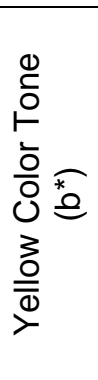 } & Wood Type $(A)$ & 2225.411 & 3 & 741.804 & 2619.957 & $0.000^{*}$ \\
\hline & Impregnate (B) & 460.984 & 1 & 460.984 & 1628.136 & $0.000^{*}$ \\
\hline & Interaction $(\mathrm{AB})$ & 807.803 & 3 & 269.268 & 951.019 & $0.000^{*}$ \\
\hline & Fungi Type (C) & 912.383 & 2 & 456.191 & 1611.210 & $0.000^{*}$ \\
\hline & Interaction (AC) & 1283.680 & 6 & 213.947 & 755.632 & $0.000^{*}$ \\
\hline & Interaction (BC) & 299.827 & 2 & 149.914 & 529.476 & $0.000^{*}$ \\
\hline & Interaction (ABC) & 403.511 & 6 & 67.252 & 237.525 & $0.000^{*}$ \\
\hline & Error & 61.157 & 216 & 0.283 & & \\
\hline & Total & 149969.412 & 240 & & & \\
\hline \multirow{9}{*}{ 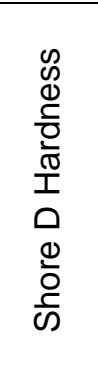 } & Wood Type $(A)$ & 10200.846 & 3 & 3400.282 & 1246.328 & $0.000^{*}$ \\
\hline & Impregnate (B) & 670.004 & 1 & 670.004 & 245.581 & $0.000^{*}$ \\
\hline & Interaction $(\mathrm{AB})$ & 786.679 & 3 & 262.226 & 96.116 & $0.000^{*}$ \\
\hline & Fungi Type (C) & 3219.733 & 2 & 1609.867 & 590.075 & $0.000^{*}$ \\
\hline & Interaction (AC) & 233.467 & 6 & 38.911 & 14.262 & $0.000^{*}$ \\
\hline & Interaction (BC) & 469.433 & 2 & 234.717 & 86.032 & $0.000^{*}$ \\
\hline & Interaction (ABC) & 573.833 & 6 & 95.639 & 35.055 & $0.000^{*}$ \\
\hline & Error & 589.300 & 216 & 2.728 & & \\
\hline & Total & 323979.000 & 240 & & & \\
\hline
\end{tabular}

Table 3 shows the statistical analysis results according to the wood species control, beeswax treatment, and fungi type for $L^{*}, a^{*}, b^{*}$, and Shore D. When wood was impregnated with $100 \%$ beeswax, the highest $L^{*}$ value of percentage change was found in beech wood with $26.8 \%$, while the lowest was seen in Scots pine with $10.6 \%$. It was seen that all $L^{*}$ values in wood species decreased after the beeswax treatment. Fungal degradation differed according to wood species in terms of the $L^{*}$ value. Red color tone $\left(a^{*}\right)$ values in all wood species increased after beeswax impregnation compared to untreated control specimens. The differences between beeswax-treated and untreated samples for red color tone values were found to be significant $(\mathrm{P} \leq 0.05)$. The positive increase in the " $a$ *" value indicated that beeswax impregnation contributed to increasing the red color 
value. The highest " $a *$ " value of percentage change for control samples was observed in poplar wood at $49 \%$, while the lowest was in Scots pine at $23.7 \%$ after wax treatment. When $b^{*}$ values were examined, it was observed that $b^{*}$ values increased in all beeswaxtreated and fungal-exposed specimens compared to control specimens. Positive increases in beeswax-treated samples indicated that beeswax impregnation also contributed to a yellow color tone. Beeswax-treated lime wood showed the highest $b^{*}$ value of percentage change, while Scots pine and poplar wood showed an almost similar percentage change when compared to un-treated control specimens. As shown in Table 3, Shore D hardness values differed according to wood species. Shore D hardness values increased in poplar and lime wood (low-density wood species) after beeswax treatment. As expected, fungal exposure negatively affected the hardness values in all wood species.

Table 3. Statistical Analysis Results for Color Parameters $\left(a^{*}, b^{*}\right.$, and $\left.L^{*}\right)$ and Shore D Hardness Before and After Fungi Tests

\begin{tabular}{|c|c|c|c|c|c|c|c|c|}
\hline \multirow{2}{*}{$\begin{array}{l}\text { Wood } \\
\text { Species }\end{array}$} & \multirow{2}{*}{ Treatment } & \multirow{2}{*}{ Fungi Species } & \multicolumn{3}{|c|}{ Lightness $\left(L^{*}\right)$} & \multicolumn{3}{|c|}{ Red Color Tone $\left(a^{*}\right)$} \\
\hline & & & Mean & $H G$ & $S D$ & Mean & $H G$ & $S D$ \\
\hline \multirow{6}{*}{$\begin{array}{l}\text { ᄃ } \\
\Phi \\
\Phi \\
\Phi\end{array}$} & \multirow{3}{*}{ Control } & Control (untreated) & 66.97 & $\mathrm{~L}$ & 0.57 & 7.99 & $E$ & 0.28 \\
\hline & & Trametes versicolor & 81.97 & $A^{*}$ & 0.33 & 4.78 & $\mathrm{~N}$ & 0.10 \\
\hline & & Neolentinus lepideus & 75.01 & $\mathrm{G}$ & 0.14 & 6.89 & $\mathrm{HI}$ & 0.30 \\
\hline & \multirow{3}{*}{ Beeswax } & $\begin{array}{l}\text { Control (wax- } \\
\text { treated) }\end{array}$ & 48.96 & S & 0.83 & 14.16 & $A^{*}$ & 0.43 \\
\hline & & Trametes versicolor & 48.18 & $T^{\star \star}$ & 0.83 & 4.08 & $P$ & 0.44 \\
\hline & & Neolentinus lepideus & 54.21 & $\mathrm{R}$ & 0.72 & 4.44 & 0 & 0.29 \\
\hline \multirow{6}{*}{$\begin{array}{l}\frac{\bar{\pi}}{0} \\
\frac{0}{0}\end{array}$} & \multirow{3}{*}{ Control } & Control (untreated) & 76.19 & $\mathrm{~F}$ & 0.66 & 3.59 & $\mathrm{R}^{* *}$ & 0.38 \\
\hline & & Trametes versicolor & 78.44 & $E$ & 1.13 & 5.09 & $\mathrm{M}$ & 0.16 \\
\hline & & Neolentinus lepideus & 79.10 & $\mathrm{D}$ & 0.71 & 5.51 & $\mathrm{~L}$ & 0.04 \\
\hline & \multirow{3}{*}{ Beeswax } & $\begin{array}{l}\text { Control (wax- } \\
\text { treated) }\end{array}$ & 58.71 & $\mathrm{P}$ & 0.31 & 7.05 & $\mathrm{FGH}$ & 0.29 \\
\hline & & Trametes versicolor & 58.27 & $\mathrm{P}$ & 0.34 & 7.31 & $\mathrm{~F}$ & 0.36 \\
\hline & & Neolentinus lepideus & 63.39 & $\mathrm{~N}$ & 1.09 & 6.74 & $\mathrm{~J}$ & 0.20 \\
\hline \multirow{6}{*}{ 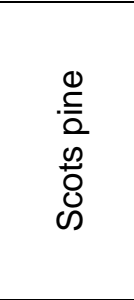 } & \multirow{3}{*}{ Control } & Control (untreated) & 79.74 & C & 0.16 & 4.62 & NO & 0.16 \\
\hline & & Trametes versicolor & 68.91 & $\mathrm{~K}$ & 0.20 & 10.84 & $\mathrm{D}$ & 0.10 \\
\hline & & Neolentinus lepideus & 69.45 & $\mathrm{~J}$ & 0.43 & 11.30 & $\mathrm{C}$ & 0.40 \\
\hline & \multirow{3}{*}{ Beeswax } & $\begin{array}{l}\text { Control (wax- } \\
\text { treated) }\end{array}$ & 71.28 & $\mathrm{H}$ & 0.31 & 6.06 & K & 0.15 \\
\hline & & Trametes versicolor & 62.55 & $\mathrm{O}$ & 1.32 & 11.97 & $\mathrm{~B}$ & 0.66 \\
\hline & & Neolentinus lepideus & 64.68 & $\mathrm{M}$ & 0.31 & 11.45 & $\mathrm{C}$ & 0.18 \\
\hline \multirow{6}{*}{$\stackrel{\oplus \Xi}{\Xi}$} & \multirow{3}{*}{ Control } & Control (untreated) & 81.78 & A & 0.09 & 4.59 & $\mathrm{NO}$ & 0.13 \\
\hline & & Trametes versicolor & 78.38 & $E$ & 0.18 & 6.92 & $\mathrm{GHI}$ & 0.13 \\
\hline & & Neolentinus lepideus & 80.85 & $B$ & 0.34 & 5.16 & $\mathrm{M}$ & 0.18 \\
\hline & \multirow{3}{*}{ Beeswax } & $\begin{array}{l}\text { Control (wax- } \\
\text { treated) }\end{array}$ & 70.41 & I & 0.30 & 7.75 & $E$ & 0.12 \\
\hline & & Trametes versicolor & 63.32 & $\mathrm{~N}$ & 0.16 & 7.18 & $F G$ & 0.30 \\
\hline & & Neolentinus lepideus & 66.78 & $\mathrm{~L}$ & 0.70 & 6.41 & $\mathrm{~J}$ & 0.27 \\
\hline \multirow{2}{*}{$\begin{array}{l}\text { Wood } \\
\text { Type }\end{array}$} & \multirow{2}{*}{$\begin{array}{c}\text { Treat- } \\
\text { ment }\end{array}$} & \multirow[t]{2}{*}{ Fungi species } & \multicolumn{3}{|c|}{$\begin{array}{l}\text { Yellow Color Tone } \\
\left(b^{\star}\right)\end{array}$} & \multicolumn{3}{|c|}{$\begin{array}{l}\text { Shore D Hardness } \\
\left(\mathrm{N} / \mathrm{mm}^{2}\right)\end{array}$} \\
\hline & & & Mean & $H G$ & $S D$ & Mean & $H G$ & $S D$ \\
\hline \multirow{4}{*}{$\begin{array}{l}\text { ㅇ } \\
\mathbb{D} \\
\Phi \\
\oplus\end{array}$} & \multirow{3}{*}{ Control } & Control (untreated) & 20.87 & $\mathrm{~J}$ & 0.34 & 52.80 & $A^{*}$ & 2.53 \\
\hline & & Trametes versicolor & 20.67 & $\mathrm{JK}$ & 0.18 & 34.60 & $\mathrm{G}$ & 0.84 \\
\hline & & Neolentinus lepideus & 29.27 & $\mathrm{C}$ & 0.25 & 45.10 & $\mathrm{D}$ & 0.99 \\
\hline & Beeswax & $\begin{array}{l}\text { Control (wax- } \\
\text { treated) }\end{array}$ & 22.94 & I & 0.41 & 49.70 & B & 0.95 \\
\hline
\end{tabular}




\begin{tabular}{|c|c|c|c|c|c|c|c|c|}
\hline & & Trametes versicolor & 18.30 & $\mathrm{~N}$ & 0.40 & 45.10 & $\mathrm{C}$ & 0.99 \\
\hline & & Neolentinus lepideus & 19.30 & $M$ & 0.14 & 44.10 & $\mathrm{C}$ & 0.32 \\
\hline & & Control (untreated) & 19.10 & $\mathrm{M}$ & 0.77 & 31.50 & $\mathrm{H}$ & 2.27 \\
\hline & Control & Trametes versicolor & 20.37 & $\mathrm{KL}$ & 0.95 & 25.40 & $\mathrm{~J}$ & 1.26 \\
\hline & & Neolentinus lepideus & 21.04 & $\mathrm{~J}$ & 0.28 & 21.30 & $\mathrm{~K}^{\star \star}$ & 0.82 \\
\hline 응 & & $\begin{array}{l}\text { Control (wax- } \\
\text { treated) }\end{array}$ & 25.96 & $\mathrm{~F}$ & 0.67 & 33.20 & G & 1.75 \\
\hline & Beeswax & Trametes versicolor & 26.52 & $\mathrm{DE}$ & 0.76 & 25.50 & $\mathrm{~J}$ & 0.53 \\
\hline & & Neolentinus lepideus & 25.95 & $\mathrm{~F}$ & 0.94 & 28.50 & $\mathrm{I}$ & 0.53 \\
\hline & & Control (untreated) & 19.97 & $\mathrm{~L}$ & 0.47 & 39.20 & $E$ & 4.83 \\
\hline & Control & Trametes versicolor & 33.89 & B & 0.20 & 29.10 & 1 & 0.74 \\
\hline :气 & & Neolentinus lepideus & 29.63 & $\mathrm{C}$ & 1.00 & 31.00 & $\mathrm{H}$ & 0.82 \\
\hline 焉 & & $\begin{array}{c}\text { Control (wax- } \\
\text { treated) }\end{array}$ & 25.16 & $\mathrm{G}$ & 0.44 & 36.80 & $\mathrm{~F}$ & 2.30 \\
\hline & Beeswax & Trametes versicolor & 35.47 & $A^{*}$ & 0.80 & 31.50 & $\mathrm{H}$ & 1.08 \\
\hline & & Neolentinus lepideus & 33.81 & $\mathrm{~B}$ & 0.18 & 28.40 & $\mathrm{I}$ & 0.52 \\
\hline & & Control (untreated) & 14.98 & $\mathrm{O}^{* *}$ & 0.16 & 40.40 & $\mathrm{DE}$ & 1.17 \\
\hline & Control & Trametes versicolor & 26.06 & $\mathrm{EF}$ & 0.26 & 27.90 & I & 1.85 \\
\hline & & Neolentinus lepideus & 20.97 & $\mathrm{~J}$ & 0.60 & 31.00 & $\mathrm{H}$ & 1.56 \\
\hline 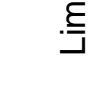 & & $\begin{array}{l}\text { Control (wax- } \\
\text { treated) }\end{array}$ & 24.59 & $\mathrm{H}$ & 0.13 & 43.70 & C & 1.83 \\
\hline & Beeswax & Trametes versicolor & 25.10 & $\mathrm{G}$ & 0.20 & 41.80 & $\mathrm{D}$ & 1.32 \\
\hline & & Neolentinus lepideus & 26.98 & $\mathrm{D}$ & 0.27 & 41.10 & $\mathrm{D}$ & 0.88 \\
\hline $\begin{array}{l}5 \mathrm{~S}: \\
{ }^{*} \mathrm{Hig} \\
{ }^{*} \mathrm{LO}\end{array}$ & $\begin{array}{l}\text { geneity } \\
\text { ard devi } \\
\text { alue } \\
\text { alue }\end{array}$ & & & & & & & \\
\hline
\end{tabular}

Table 4 shows the total color changes observed due to wax treatment and fungal exposure in varying wood species. The highest total color change $\left(\Delta E^{*}\right)$ was found in Scots pine and beech control and beeswax-treated samples exposed to fungi. It was thought that because of their light color tone, poplar and lime wood were not affected during the fungal degradation. In fungal-exposed specimens, higher total color change values were recorded in control woods than in beeswax-treated ones because beeswax protected wood against fungal degradation.

When the total color change values for beeswax-treated specimens were examined, the highest color change $\left(\Delta E^{*}\right)$ was found in beech and poplar wood, i.e. 19.15 and 19.12, respectively. The total color change of Scots pine was the lowest by 10.04 , compared to the other wood species. The total color change was found negative for $\Delta L^{*}$ and positive for $\Delta a^{*}, \Delta b^{*}$, and $\Delta E^{*}$ in all wood species.

The complicated chemical composition of beeswax caused color change in wood. Its chemical composition consists of 15 different compounds that are divided into three main groups: fatty acids, esters, and saturated hydrocarbons. There are some small quantities of dyes and essential oils in beeswax, and these small quantities determine the beeswax color. Natural beeswax color can range between white and light brown. However, a good color is the color of lemon (Istrefi et al. 2017).

It was stated that impregnating wood with wax plays an important role in increasing the hardness of the wood (Esteves et al. 2014). Investigations confirmed an increase in hardness of up to $189 \%$ (lateral) as well as $86 \%$ (longitudinal) for wax-impregnated beech (Fagus sylvatica L.) wood (Scholz et al. 2010a,b). 
Table 4. Total Color Changes $\left(\Delta L^{*}, \Delta a^{*}, \Delta b^{*}\right.$, and $\left.\Delta E^{*}\right)$

\begin{tabular}{|c|c|c|c|c|c|c|}
\hline Wood Species & Treatment & Fungal Species & $\Delta L$ & $\Delta a$ & $\Delta b$ & $\Delta E$ \\
\hline \multirow{4}{*}{ Beech } & \multirow{2}{*}{ Control (un-impregnated) } & Trametes versicolor & 15.01 & -3.21 & -0.20 & 15.36 \\
\hline & & Neolentinus lepideus & 8.04 & -1.10 & 8.40 & 11.70 \\
\hline & \multirow{2}{*}{$\begin{array}{c}\text { Beeswax } \\
\text { (impregnated) }\end{array}$} & Trametes versicolor & -0.78 & -10.09 & -4.64 & 11.18 \\
\hline & & Neolentinus lepideus & 5.25 & -9.73 & -3.64 & 11.68 \\
\hline \multirow{4}{*}{ Poplar } & \multirow{2}{*}{ Control (un-impregnated) } & Trametes versicolor & 2.25 & 1.50 & 1.27 & 3.37 \\
\hline & & Neolentinus lepideus & 2.91 & 1.91 & 1.94 & 4.10 \\
\hline & \multirow{2}{*}{$\begin{array}{c}\text { Beeswax } \\
\text { (impregnated) }\end{array}$} & Trametes versicolor & -0.44 & 0.26 & 0.56 & 1.24 \\
\hline & & Neolentinus lepideus & 4.68 & -0.32 & -0.02 & 4.79 \\
\hline \multirow{4}{*}{ Scots pine } & \multirow[b]{2}{*}{ Control (un-impregnated) } & Trametes versicolor & -10.83 & 6.22 & 13.92 & 18.70 \\
\hline & & Neolentinus lepideus & $\mid-10.29$ & 6.68 & 9.66 & 15.63 \\
\hline & \multirow[t]{2}{*}{$\begin{array}{c}\text { Beeswax } \\
\text { (impregnated) }\end{array}$} & Trametes versicolor & -8.73 & 5.90 & 10.31 & 14.76 \\
\hline & & Neolentinus lepideus & -6.60 & 5.39 & 8.65 & 12.16 \\
\hline \multirow{4}{*}{ Lime } & \multirow{2}{*}{ Control (untreated)) } & Trametes versicolor & -3.41 & 2.33 & 11.08 & 11.82 \\
\hline & & Neolentinus lepideus & -0.93 & 0.57 & 5.98 & 6.10 \\
\hline & \multirow{2}{*}{$\begin{array}{c}\text { Beeswax } \\
\text { (impregnated) }\end{array}$} & Trametes versicolor & -7.09 & -0.56 & 0.51 & 7.14 \\
\hline & & Neolentinus lepideus & -3.63 & -1.33 & 2.39 & 4.60 \\
\hline \multicolumn{7}{|c|}{ Beeswax Treatment } \\
\hline \multicolumn{3}{|c|}{ Wood Species } & $\Delta \mathrm{L}$ & $\Delta a$ & $\Delta \mathrm{b}$ & $\Delta E$ \\
\hline \multirow{2}{*}{\multicolumn{3}{|c|}{ Beech }} & $\mid-18.01$ & 6.17 & 2.07 & 19.15 \\
\hline & & & -17.48 & 3.46 & 6.86 & 19.12 \\
\hline \multicolumn{3}{|c|}{ Scots pin } & -8.46 & 1.44 & 5.18 & 10.04 \\
\hline \multicolumn{3}{|c|}{ Lime } & -11.38 & 3.16 & 9.61 & 15.2 \\
\hline
\end{tabular}

\section{CONCLUSIONS}

1. Water uptake properties decreased, while antifungal, and color properties were increased in wood impregnated with honeybee wax.

2. Scanning electron microscopy images indicated that beeswax-impregnated samples were more durable against fungi decay compared to un-impregnated control samples.

3. Deep beeswax treatment showed a larvicidal effect on H. bajulus.

4. The surface hardness of the poplar and lime wood species (low-density woods) increased after beeswax impregnation.

5. Fungal exposure negatively affected surface hardness of the beeswax-impregnated wood.

\section{ACKNOWLEDGMENTS}

This work was supported by the Düzce University Scientific Research Projects in Turkey by Grant No. 2020.02.03.1098. The author would like to thank Associate Professor Ümit Ayata of Bayburt University, Turkey, for determining the color and hardness properties of beeswax-impregnated woods, as well as for the measurements of color and Shore D hardness. 


\section{REFERENCES CITED}

ASTM D2240-15 (2010). "Standard test method for rubber property-Durometer hardness," ASTM International, West Conshohocken, PA, USA.

ASTM D2244-16 (2016). "Standard practice for calculation of color tolerances and color differences from instrumentally measured color coordinates," ASTM International, West Conshohocken, PA, USA.

Ayata, U. (2019). "Effects of artificial weathering on the surface properties of ultraviolet varnish applied to lemonwood (Citrus limon (L.) Burm.)," BioResources 14(4), 83138323. DOI: 10.15376/biores.14.4.8313-8323

Bogdanov, S. (2009). "Beeswax: Uses and trade," in: The Beeswax Book, Bee Product Science, www.bee-hexagon.net.

Ding, W. D., Koubaa, A., and Chaala, A. (2012). "Dimensional stability of methyl methacrylate hardened hybrid poplar wood," BioResources 7(1), 504-520. DOI: 10.15376/biores.7.1.504-520

EN 46-1 (2016). "Wood preservatives. Determination of the preventive action against recently hatched larvae of Hylotrupes bajulus (Linnaeus) - Part 1: Application by surface treatment (laboratory method)," European Committee for Standardization, Brussels, Belgium.

EN 47. (2016). "Wood preservatives. Determination of the toxic values against larvae of Hylotrupes bajulus (Linnaeus) (laboratory method)," European Committee for Standardisation, Brussels.

EN 113 (1996). "Wood preservatives. Test method for determining the protective effectiveness against wood destroying basidiomycetes. Determination of the toxic values," European Committee for Standardization, Brussels, Belgium.

Esteves, B., Nunes, L., Domingos, I., and Pereira, H. (2014). "Improvement of termite resistance, dimensional stability and mechanical properties of pine wood by paraffin impregnation," Holz als Roh- und Werkstoff 72(5), 609-615. DOI: 10.1007/s00107014-0823-7

Gaillard, Y., Mija, A., Burr, A., Darque-Ceretti, E., Felder, E., and Sbirrazzuoli, N. (2011). "Green material composites from renewable resources: Polymorphic transitions and phase diagram of beeswax/rosin resin," Thermochimica Acta 521(1-2), 90-97. DOI: 10.1016/j.tca.2011.04.010

Istrefi, Q., Krasniqi, R., Rifati-Nixha, A., Kastrati, K., Krasniqi, F., and Përzhaku, E. (2017). "Physico-chemical properties of ginger oil, bee wax and black seeds," in: Proceedings of the UBT International Conference, Durres, Albania, pp. 121-127. DOI: $10.33107 /$ ubt-ic.2017.169

Kartal, S. N., Hwang, W. J., Imamura, Y., and Sekine, Y. (2006). "Effect of essential oil compounds and plant extracts on decay and termite resistance of wood," Holz als Roh-und Werkstoff 64(6), 455. DOI: 10.1007/s00107-006-0098-8

Krupa, I., and Luyt, A. S. (2001). "Mechanical properties of uncrosslinked and crosslinked linear low-density polyethylene/wax blends," Journal of Applied Polymer Science 81(4), 973-980. DOI: 10.1002/app.1519

Lesar, B., and Humar, M. (2011). "Use of wax emulsions for improvement of wood durability and sorption properties," European Journal of Wood and Wood Products 69(2), 231-238. DOI: 10.1007/s00107-010-0425-y 
Lesar, B., Pavlič, M., Petrič, M., Škapin, A. S., and Humar, M. (2011). "Wax treatment of wood slows photodegradation," Polymer Degradation and Stability 96(7), 12711278. DOI: 10.1016/j.polymdegradstab.2011.04.006

Li, Y., Qian, J., Wang, Z., Qu, L., Gao, J., Yi, S., and He, Z. (2020). “Effect of beeswax impregnation on the dimensional stability, surface properties, and thermal characteristics of wood," BioResources 15(2), 2181-2194. DOI: 10.15376/biores.15.2.2181-2194.

Lozhechnikova, A., Bellanger, H., Michen, B., Burgert, I., and Österberg, M. (2017). "Surfactant-free carnauba wax dispersion and its use for layer-by-layer assembled protective surface coatings on wood," Applied Surface Science 396, 1273-1281.

Marquez, R., Bálsamo, S., Morales, F., Ruiz, N., García, A., León, R., Montes, A., Nava, N., Noguera, Y., Quintero, A., et al. (2019). "Technological use of beeswax for obtaining organic products, non-toxic for the human being," Revista Ciencia e Ingeniería 40(1), 17-26.

Mladenoska, I. (2012). "The potential application of novel beeswax edible coatings containing coconut oil in the minimal processing of fruits," Advanced Technologies $1(2), 26-34$.

Morgan, J., Townley, S., Kemble, G., and Smith, R. (2002). "Measurement of physical and mechanical properties of beeswax," Materials Science and Technology 18(4), 463-467. DOI: 10.1179/026708302225001714

Németh, R., Tsalagkas, D., and Bak, M. (2015). "Effect of soil contact on the modulus of elasticity of beeswax-impregnated wood," BioResources 10(1), 1574-1586. DOI: 10.15376/biores.10.1.1574-1586

Ren, L., Cai, Y., Ren, L., and Yang, H. (2016). "Preparation of modified beeswax and its influence on the surface properties of compressed poplar wood," Materials 9(4), Article number 230. DOI: 10.3390/ma9040230

Scholz, G., Krause, A., and Militz, H. (2010b). "Beeinflussung der holzfestigkeit durch wachstränkung. Holztechnologie 51(3), 22-27.

Scholz, G., Militz, H., Gascón-Garrido, P., Ibiza-Palacios, M. S., Oliver-Villanueva, J. V., Peters, B. C., and Fitzgerald, C. J. (2010a). "Improved termite resistance of wood by wax impregnation," International Biodeterioration \& Biodegradation 64(8), 688693. DOI: 10.1016/j.ibiod.2010.05.012

Tulloch, A. P. (1980). "Beeswax-composition and analysis," Bee World 61(2), 47-62. DOI: $10.1080 / 0005772 X .1980 .11097776$

Zhang, Y., Jin, J., and Wang, S. (2007). "Effects of resin and wax on the water uptake behavior of wood strands," Wood and Fiber Science 39(2), 271-278.

Article submitted: July 20, 2020; Peer review completed: August 29, 2020; Revised version received and accepted: September 10, 2020; Published: September 16, 2020. DOI: 10.15376/biores.15.4.8339-8354 